Polymer Journal, Vol. 5, No. 1, pp 105-106 (1973)

SHORT COMMUNICATION

\title{
Electroinitiated Polyesters from Phthalic Anhydride and Propylene Oxide
}

\author{
Richard A. Wallace and N. V. Vijayaraghavan \\ Department of Materials Science and Engineering, Stanford University \\ Stanford, California 94305 \\ (Recsived January 29, 1973)
KEY WORDS Electroinitiation / Polyester Synthesis / Phthalic Anhydride / Propylene Oxide / NMR / IR /

Electroinitiated polymerizations have been applied mostly to vinyl monomers. ${ }^{1-3}$ For instance, Funt and coworkers ${ }^{4-7}$ have studied electroinitiated vinyl polymerization of methyl methacrylate, acrylonitrile and styrene. Nonvinyl monomers such as benzene, ${ }^{8}$ pyridine ${ }^{9}$ and substituted xylenes ${ }^{10}$ have been electropolymerized by means of anionic mechanism. The initiation occurred by electrons released at the cathode. Recently, electrochemical condensation of $4,4^{\prime}$ diacetyldiphenylethane to polypinacols has been reported by Laube and Higgins. ${ }^{11}$ No investigations have been carried out related to the synthesis of polyesters from anhydride and epoxides using electroinitiation. In this communication, we wish to present the previously unreported electroinitiated polyester synthesis from the reaction of propylene oxide with phthalic anhydride.

The reaction was carried out in DMF at $25^{\circ} \mathrm{C}$ using carbon electrodes and $\mathrm{LiCl}$ as the electrolyte. At a current density of $20 \mathrm{~mA} / \mathrm{cm}^{2}$ and at a constant voltage of $10 \mathrm{~V}$ applied for $23 \mathrm{hr}$, a polyester having an average molecular weight of 3500 based on the acid number was obtained.
The polyester yield was about 54\%. When the reaction time was extended to $30 \mathrm{hr}$, the polyester yield increased to about $60 \%$. However, when the current density was varied from 10 to 40 $\mathrm{mA} / \mathrm{cm}^{2}$, neither the yield nor the molecular weight of the polyester changed.

The IR absorption spectrum of the polyester displayed a strong peak at $1725 \mathrm{~cm}^{-1}$ indicative of the ester carbonyl. ${ }^{12}$ This peak was absent in the spectrum of the reactants. Homopolymerization of the epoxide had not occurred as demonstrated from the NMR spectrum of the polyester. The ratio of the methyl to aromatic protons was $3: 4$. This ratio also suggests that the anhydride had opened the epoxide ring to form the polyester with $\mathrm{OH}$ and $\mathrm{COOH}$ groups at the two ends of the polyester. A portion of the polyester when hydrolysed with aqueous $\mathrm{KOH}$, gave phthalic acid and 1,2-propanediol.

We believe that the mechanism of initiation of polyesterification occurs as a result of electron addition to phthalic anhydride and thus the anhydride ring opens to form a radical anion. This in turn reacts with the epoxide to form the<smiles>CC(COC(=O)c1ccccc1C(=O)OC(C)CC(C)C(C)O)OC(=O)c1ccccc1C(=O)O</smiles> 


\section{R. A. Wallace and N. V. Vijayaraghavan}

polyester. This electroinitiation step is similar to other systems previously reported..$^{13,14}$

\section{EXPERIMENTAL}

In a $500-\mathrm{m} l$ cylindrical pyrex cell $7.5 \mathrm{~cm}$ in diameter were placed $100 \mathrm{ml}$ of DMF, $49.0 \mathrm{~g}$ $(0.3 \mathrm{~mol})$ of phthalic anhydride, $29.0 \mathrm{~g}(0.5 \mathrm{~mol})$ of propylene oxide, and $1.0 \mathrm{~g}$ of $\mathrm{LiCl}$. Two carbon electrodes $0.6 \mathrm{~cm}$ in diameter were kept $3.75 \mathrm{~cm}$ apart in solution. The leads to the electrodes were placed through a tight-fitting teflon cap which carried a reflux condenser and a gas inlet tube. The solution was flushed for a few minutes with dry nitrogen and placed in a silicone-oil bath maintained at $25^{\circ} \mathrm{C} \pm 0.1$. The solution was agitated by a magnetic stirrer and when it became homogeneous a constant voltage of $10 \mathrm{~V}$ was applied for $23 \mathrm{hr}$ by Trigon Electronics model HR 40-750. The current was measured with a Keithley electrometer model 610-Q. During the course of the reaction, the acid values were determined and when this value reached a constant the electrolysis was terminated. Excess propylene oxide was removed under reduced pressure and the residue was poured into $500-\mathrm{m} l$ water. A light-yellow viscous mass separated. This was washed several times with water, dissolved in 500-m $l$ xylene and dried over $\mathrm{Na}_{2} \mathrm{SO}_{4}$. The solvent was removed under reduced pressure and the yellow residue obtained was dried in vacuo at $50^{\circ} \mathrm{C}$ for $24 \mathrm{hr}$; yield, $36 \mathrm{~g}$ (54\% based on anhydride).

The IR absorption spectrum (film) showed principal bands at $3500(\mathrm{mw}), 2980(\mathrm{~ms}), 1725$ (s), $1630(\mathrm{~m}), 1600(\mathrm{~m}), 1580(\mathrm{~m}), 1485(\mathrm{~m}), 1450$ $(\mathrm{m}), 1380(\mathrm{~m}), 1270(\mathrm{~s}$, broad), $1130(\mathrm{~s}), 1065$ (s), $850(\mathrm{mw}), 780(\mathrm{~ms}), 750(\mathrm{~s}), 710(\mathrm{~ms})$. The acid number of the polyester was 16 .
Acetone and tetrahydrofuran each containing $1-\% \mathrm{LiCl}$ were also investigated under the conditions described above. In acetone solvent a polymer with an average molecular weight of 2900 (acid number 19.0) was isolated in 42-\% yield. In tetrahydrofuran no polymer was obtained.

\section{REFERENCES}

1. J. W. Breitenbach and Ch. Srna, Pure Appl. Chem., 4, 245 (1962).

2. H. Z. Friedlander, "Encyclopedia of Polymer Science and Technology," Vol. 5, H. F. Mark, Ed., Interscience, New York, N.Y. 1970, p 629.

3. B. M. Tidswell, Rep. Progr. Appl. Chem., 53, 516 (1968).

4. B. L. Funt and K. C. Yu, J. Polym. Sci., 62, 359 (1962).

5. B. L. Funt and F. D. Williams, ibid., Part $A$, 2, 865 (1964).

6. B. L. Funt and S. N. Bhadani, Can. J. Chem., 42, 2733 (1964).

7. B. L. Funt and F. D. Williams, J. Polym. Sci., Part B, 1, 181 (1963).

8. A. F. Shepard and B. F. Dannels, ibid., Part $A-1,4,511$ (1966).

9. A. I. Fedorova and S. Ya. Vasina, Electrokhim, 3, 653 (1967).

10. H. Gilch, J. Polym. Sci., Part A-1, 4, 1351 (1966).

11. B. L. Laube and J. Higgins, ibid., Part $A-1$, 10, 2389 (1972).

12. K. Nakanishi, "Infrared Absorption Spectroscopy," Holden-Day Inc., San Francisco, Calif., 1962, p 44.

13. H. Gilch and D. Michael, Makromol. Chem., 99, 103 (1966).

14. B. L. Funt and S. N. Bhadani, J. Polym. Sci., Part A-1, 3, 4191 (1965). 